\title{
MODELLING THE PERMEABILITY CHARACTERISTICS OF AN EARTH RESERVOIR
}

\author{
A. Mohammed ${ }^{1}$ and A. Y. Abdulfatah ${ }^{2 * *}$ \\ 1, 2, Department of Civil Engineering, Bayero University, Kano, KANo State, NIGERIA \\ E-mail addresses: ${ }^{1}$ trophygroup2010@gmail.com, ${ }^{2}$ ayabdulfatah.civ@buk.edu.ng
}

\begin{abstract}
Particle size distribution and void ratio of a soil are considered as the direct information that can be used in a relatively easy manner for hydraulic conductivity estimation. Estimation of hydraulic conductivity from particle size distribution can be used to check permeability values obtained from other methods. Therefore, this paper attempts to relate the particle size distribution to hydraulic conductivity. The study was carried out on 24 soil samples which were collected from the embankment of an earth reservoir and subgrade at the toe. The investigation was carried out in accordance with the standard procedure given in BS1377. A series of hydraulic conductivity tests were carried out on optimum moisture content (OMC) compacted soil samples using the falling head method. The mean sizes of particles in each sample from particle size distribution curves were determined and used to generate regression models for the flow. Linear, exponential, polynomial and logarithmic models were used to test the validity; however, the best was adopted for this study. The findings of this study show that there is variability in the particle sizes of the soil material which in turn results to variation in the hydraulic conductivity. The hydraulic conductivity was found to increase with an increase in mean particle size. The relationship between mean particle size and hydraulic conductivity yielded coefficients of determination $\left(R^{2}\right)$ of stronger correlation when the plastic and non-plastic samples were separately analyzed. However, all values of $R^{2}(0.9949,0.9968$ and 0.8918 for samples 1 to 16,17 to 24 and 1 to 24 respectively) can be considered satisfactory. In addition, generalized models for the flow were generated for the plastic, non-plastic and the combined samples. The generated models can be used to predict the hydraulic conductivity of different soil samples.
\end{abstract}

Keywords: Model, Hydraulic Conductivity, Mean Particle Size, Earth Reservoir

\section{INTRODUCTION}

Seepage through soils may affect the stability of geotechnical structures such as pavements, tunnels, walls, slopes and excavations [1]. In order to solve fluid flow problems associated with soil, different techniques were proposed some of which include the field methods (the pumping-of-wells test, the augerhole test and the tracer test), laboratory methods (the falling-head test, the constant-head test) and calculations from empirical formulae [2]. Many researchers have made attempts in solving hydraulic conductivity problems in soil. However, published hydraulic conductivity equations based on the porosity and grain-size distribution of sandy sediments are used by researchers to estimate the hydraulic conductivity of well core. These equations are based on empirical studies and the results are not necessarily transferable from one location to another [3]. In addition, some of the formulated models vary in accuracy as was seen in [4] who have recently employed several empirical formulae to specify the hydraulic conductivity of aquifer materials in the field. They stated that the most accurate estimation of the hydraulic conductivity was found using the Terzaghi equation, followed by the Kozeny-Carman, Hazen, Breyer and Slitcher equations respectively.

\footnotetext{
${ }^{*}$ Corresponding author, tel: $+234-806-603-1086$
} 
Hydraulic conductivity is one of the most important properties of soils [5]. Hydraulic conductivity is affected by pores space, structures and sizes of the soil, however, according to [6] estimation of hydraulic conductivity using particle size distribution is relatively simple and straightforward. Pore size distribution, which is intimately linked to the grain size distribution, is frequently involved in the determination of hydraulic conductivity. In addition, it is widely known that the hydraulic conductivity is related to the particle size distribution of the soil grains $[7,8]$. Particle size distribution is considered as the direct information that can be used in a relatively easy manner for hydraulic conductivity estimation [9]. Global studies of hydraulic conductivity of marine sediments have shown that grain size exerts a first-order control on hydraulic conductivity $[10,11]$. Estimation of hydraulic conductivity from particle size distribution can be used to check permeability values obtained from other methods. Therefore, this paper attempts to relate the particle size distribution to hydraulic conductivity of soils.

\section{MATERIALS AND METHOD}

The study was carried out on an existing and abandoned earth reservoir $200 \mathrm{~m}$ by $200 \mathrm{~m}$. The reservoir with about $120,000 \mathrm{~m}^{3}$ capacity was constructed for irrigation purpose and is located around Challawa Gorge Dam in Karaye Local Government, Kano-Nigeria. Challawa Gorge Dam is the main source of water for the reservoir. The dam was built by Julius Berger Nigeria between 1990 and 1992 using rock fill construction. It is $42 \mathrm{~m}$ high and $7.8 \mathrm{~km}$ in length. The dam has a full storage capacity of $904,000,000 \mathrm{~m}^{3}$. The direct catchment area is $3857 \mathrm{~km}^{2}$. The reservoir, during the study was virtually empty. Twenty-four (24) disturbed samples were collected from the embankment and subgrade at the toe of the reservoir for laboratory analyses as shown in Figure 1. GPS set to WGS 84 Map datum was used to take the coordinate of the sampling points as shown in Table 1 . Samples 1 to 16 were collected from the embankment and 17 to 24 from the subgrade at the toe of the reservoir with 6 samples each representing one side of the rectangular reservoir.

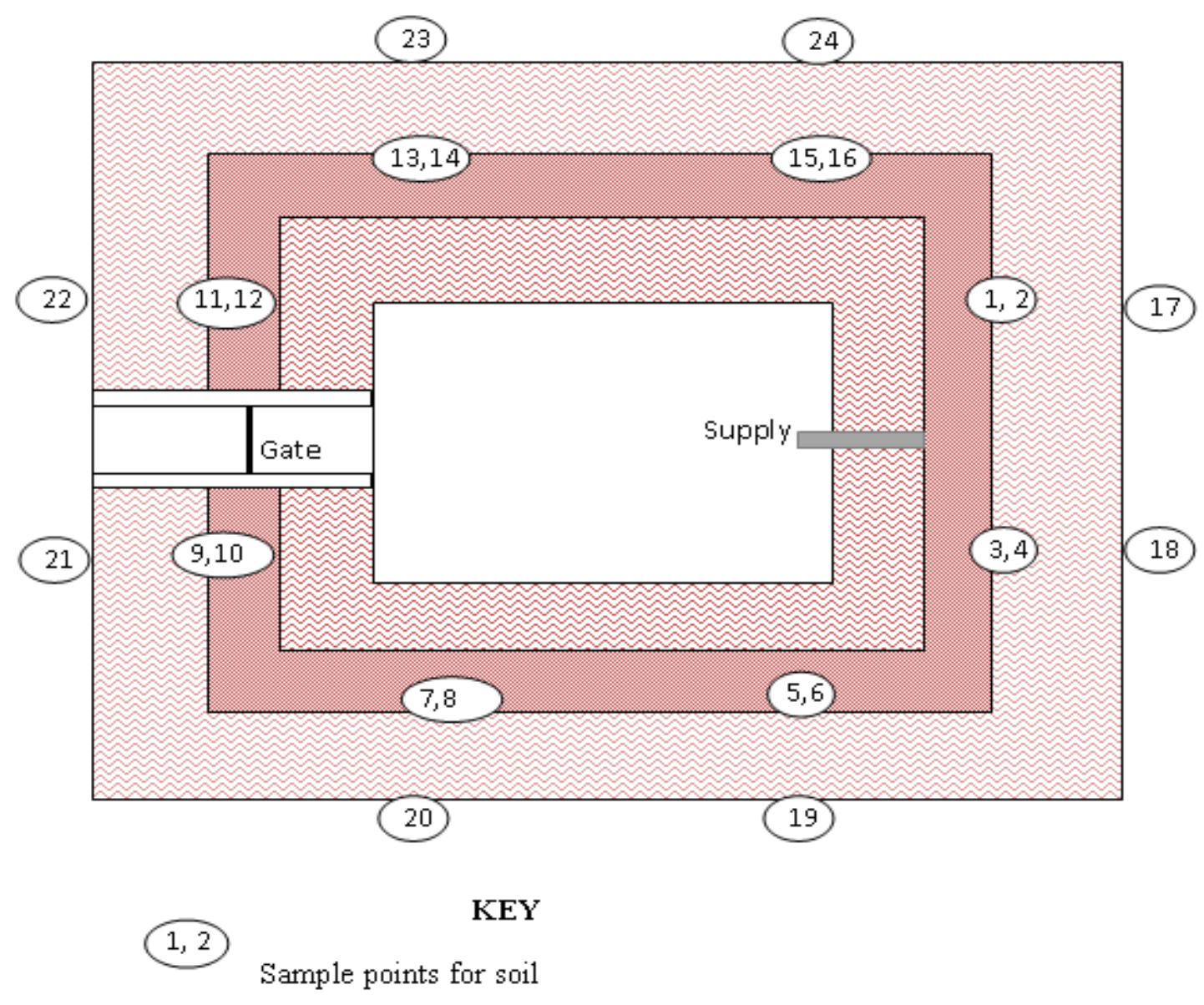

Figure 1: Sampling Points 
Table 1: Sampling Points Coordinates and Sample Identification

\begin{tabular}{|c|c|c|c|}
\hline $\begin{array}{l}\text { Sam } \\
\text { ples }\end{array}$ & $\begin{array}{l}\text { Way } \\
\text { Points }\end{array}$ & Coordinates & Depth \\
\hline 1 & 001 & $\begin{array}{cc}32 P & 0394128 \\
\text { UTM } & 1300957\end{array}$ & $\begin{array}{c}1.5 \mathrm{~m} \text { from } \\
\text { the Top }\end{array}$ \\
\hline 2 & 003 & $\begin{array}{cc}32 P & 0394127 \\
\text { UTM } & 1300951\end{array}$ & $\begin{array}{c}2.5 \mathrm{~m} \text { from } \\
\text { the Top }\end{array}$ \\
\hline 3 & 002 & $\begin{array}{cc}32 P & 0394105 \\
\text { UTM } & 1300975\end{array}$ & $\begin{array}{l}1.5 \mathrm{~m} \text { from } \\
\text { the Top }\end{array}$ \\
\hline 4 & 004 & $\begin{array}{cc}32 P & 0394108 \\
\text { UTM } & 1300974\end{array}$ & $\begin{array}{c}2.5 \mathrm{~m} \text { from } \\
\text { the Top }\end{array}$ \\
\hline 5 & 005 & $\begin{array}{cc}32 P & 0394102 \\
\text { UTM } & 1301004\end{array}$ & $\begin{array}{l}1.5 \mathrm{~m} \text { from } \\
\text { the Top }\end{array}$ \\
\hline 6 & 007 & $\begin{array}{cc}\text { 32P } & 0394107 \\
\text { UTM } & 1301007\end{array}$ & $\begin{array}{l}2.5 \mathrm{~m} \text { from } \\
\text { the Top }\end{array}$ \\
\hline 7 & 006 & $\begin{array}{cc}32 P & 0394129 \\
\text { UTM } & 1301022\end{array}$ & $\begin{array}{c}1.5 \mathrm{~m} \text { from } \\
\text { the Top }\end{array}$ \\
\hline 8 & 008 & $\begin{array}{c}32 P \\
\text { 32P } \\
\text { UTM } 1301028\end{array}$ & $\begin{array}{l}2.5 \mathrm{~m} \text { from } \\
\text { the Top }\end{array}$ \\
\hline 9 & 009 & $\begin{array}{cc}32 P & 0394172 \\
\text { UTM } & 1301041\end{array}$ & $\begin{array}{l}1.5 \mathrm{~m} \text { from } \\
\text { the Top }\end{array}$ \\
\hline 10 & 011 & $\begin{array}{cc}\text { 32P } & 0394172 \\
\text { UTM } & 1301040\end{array}$ & $\begin{array}{c}2.5 \mathrm{~m} \text { from } \\
\text { the Top }\end{array}$ \\
\hline 11 & 010 & $\begin{array}{cc}32 P & 0394204 \\
\text { UTM } & 1300992\end{array}$ & $\begin{array}{c}1.5 \mathrm{~m} \text { from } \\
\text { the Top }\end{array}$ \\
\hline 12 & 012 & $\begin{array}{cc}\text { 32P } & 0394207 \\
\text { UTM } & 1300999\end{array}$ & $\begin{array}{c}2.5 \mathrm{~m} \text { from } \\
\text { the Top }\end{array}$ \\
\hline 13 & 014 & $\begin{array}{cc}32 P & 0394204 \\
\text { UTM } & 1300978\end{array}$ & $\begin{array}{c}1.5 \mathrm{~m} \text { from } \\
\text { the Top }\end{array}$ \\
\hline 14 & 017 & $\begin{array}{lr}32 P & 0394208 \\
\text { UTM } & 1300976\end{array}$ & $\begin{array}{c}2.5 \mathrm{~m} \text { from } \\
\text { the Top }\end{array}$ \\
\hline 15 & 013 & $\begin{array}{cc}32 P & 0394171 \\
\text { UTM } & 1300948\end{array}$ & $\begin{array}{l}1.5 \mathrm{~m} \text { from } \\
\text { the Top }\end{array}$ \\
\hline 16 & 016 & $\begin{array}{l}\text { 32P } 0394174 \\
\text { UTM } 1300949\end{array}$ & $\begin{array}{l}2.5 \mathrm{~m} \text { from } \\
\text { the Top }\end{array}$ \\
\hline 17 & 025 & $\begin{array}{l}\text { Toe of the Reservoir } \\
\text { (Ground level below) }\end{array}$ & $\begin{array}{l}1.5 \mathrm{~m} \text { from } \\
\text { the Top }\end{array}$ \\
\hline 18 & 024 & $\begin{array}{l}\text { Toe of the Reservoir } \\
\text { (Ground level below) }\end{array}$ & $\begin{array}{c}2.5 \mathrm{~m} \text { from } \\
\text { the Top }\end{array}$ \\
\hline 19 & 023 & $\begin{array}{l}\text { Toe of the Reservoir } \\
\text { (Ground level below) }\end{array}$ & $\begin{array}{l}1.5 \mathrm{~m} \text { from } \\
\text { the Top }\end{array}$ \\
\hline 20 & 021 & $\begin{array}{l}\text { Toe of the Reservoir } \\
\text { (Ground level below) }\end{array}$ & $\begin{array}{c}2.5 \mathrm{~m} \text { from } \\
\text { the Top }\end{array}$ \\
\hline 21 & 020 & $\begin{array}{l}\text { Toe of the Reservoir } \\
\text { (Ground level below) }\end{array}$ & $\begin{array}{c}1.5 \mathrm{~m} \text { from } \\
\text { the Top }\end{array}$ \\
\hline 22 & 019 & $\begin{array}{l}\text { Toe of the Reservoir } \\
\text { (Ground level below) }\end{array}$ & $\begin{array}{l}2.5 \mathrm{~m} \text { from } \\
\text { the Top }\end{array}$ \\
\hline 23 & 018 & $\begin{array}{l}\text { Toe of the Reservoir } \\
\text { (Ground level below) }\end{array}$ & $\begin{array}{c}1.5 \mathrm{~m} \text { from } \\
\text { the Top }\end{array}$ \\
\hline 24 & 015 & $\begin{array}{l}\text { Toe of the Reservoir } \\
\text { (Ground level below) }\end{array}$ & $\begin{array}{c}2.5 \mathrm{~m} \text { from } \\
\text { the Top }\end{array}$ \\
\hline
\end{tabular}

The Index and Engineering properties were determined in accordance with the standard procedure given in BS1377. The specific gravity $\left(G_{s}\right)$ was determined using the gas jar method as given in Equation 1.

$$
G_{s}=\frac{\left(w_{2}-w_{1}\right)}{\left(w_{4}-w_{1}\right)-\left(w_{3}-w_{2}\right)}
$$

Where;

$\mathrm{w}_{1}=$ weight of empty bottle $(\mathrm{g})$

$\mathrm{w}_{2}=$ weight of empty bottle plus soil $(\mathrm{g})$

$\mathrm{W}_{3}=$ weight of empty bottle plus soil filled with water

(g)

$\mathrm{W}_{4}=$ weight of bottle filled with water $(\mathrm{g})$

The liquid limit which represents the moisture content at 25 blows was determined using Cassagrande apparatus. The plastic limit was determined by rolling a ball formed with about 8 to $10 \mathrm{gm}$ of the specimen between the fingers and the glass plate with just sufficient pressure to roll the mass into a thread of uniform diameter of $3 \mathrm{~mm}$ throughout its length. The plasticity index is taken as the difference between the liquid limit and the plastic limit. BS light compaction was used for the soil compaction test using $2.5 \mathrm{~kg}$ rammer and 27 blows in 3 layers in $1000 \mathrm{~cm}^{3}$ compaction mould. The maximum dry density (MDD) and optimum moisture content (OMC) were taken as the dry density and moisture content corresponding to the peak of the dry density - moisture content plots. The hydraulic conductivity tests were carried out on optimum moisture content (OMC) compacted soil samples using the falling head method as given in Equation 2.

$$
k=\frac{2.3 a L}{A t} \cdot \log _{10} \frac{h_{1}}{h_{2}}
$$

Where;

$\mathrm{k}=$ hydraulic conductivity $(\mathrm{cm} / \mathrm{s})$

$\mathrm{L}=$ infiltration length $(\mathrm{cm})$

$\mathrm{a}=$ pipe cross-sectional area $\left(\mathrm{cm}^{2}\right)$

$A=$ mould cross-sectional area $\left(\mathrm{cm}^{2}\right)$

$\mathrm{t}=$ the measurement time (s)

$\mathrm{h}_{1}=$ initial head pressure $(\mathrm{cm})$

$\mathrm{h}_{2}=$ final head pressure $(\mathrm{cm})$

The mean sizes of particles in each sample from particle size distribution curves were determined using Equation 3 and used to generate regression model for the flow. The following models; Linear, exponential, polynomial and logarithmic were used to test the validity; however, the best was adopted for this study.

$$
D_{\text {mean }}=\frac{\Sigma \mathrm{Pd}}{\Sigma \mathrm{P}}
$$

Where; $\mathrm{P}=$ Percentage passing $(\%), \mathrm{d}=$ Particle size (mm) 


\section{RESULTS AND DISCUSSION}

Table 2 shows the maximum dry density (MDD), optimum moisture content (OMC), Plasticity index, relative density and specific gravity of the soil. The results show that the material for the embankment varies with sampling point. This is an indication of variability in seepage through the soil materials. The particle size distribution curves are presented in Figures $2-4$. The curves show that samples 1, 2, 6, $8,9,10,12,14$ and 15 are clayey sand with gravel; 3 and 13 are clayey gravel with sand; 4, 5 and 7 are silty gravel with sand; 11 is silty sand with gravel; 16 is clayey sand; $17,22,23$ and 24 are silty sand with gravel and 18, 19, 20 and 21 are silty sand. This classification is based on the unified system of classification.

The Figures $2-4$ show the variability in the particle sizes of the soil material. This variability was also shown by the mean particle sizes as given in Table 3 . The study indicated that the hydraulic conductivity increased with an increase in mean particle size. This variation could be attributed to the variation in particle size contents.
Table 2: Samples MDD, OMC, Plasticity index and

\begin{tabular}{ccccc}
\multicolumn{5}{c}{ Specific gravity } \\
\hline $\begin{array}{c}\text { Sample } \\
\text { No }\end{array}$ & $\begin{array}{c}\text { MDD } \\
\left(\mathrm{Mg} / \mathrm{m}^{3}\right)\end{array}$ & $\begin{array}{c}\text { OMC } \\
(\%)\end{array}$ & $\begin{array}{c}\text { Plasticity } \\
\text { Index }(\%)\end{array}$ & $\begin{array}{c}\text { Specific } \\
\text { Gravity }\end{array}$ \\
\hline 1 & 1.95 & 13.8 & 12 & 2.77 \\
2 & 1.99 & 11.13 & 10 & 2.72 \\
3 & 1.96 & 13.0 & 12 & 2.56 \\
4 & 2.07 & 11.4 & 7 & 2.78 \\
5 & 2.06 & 14.7 & 7 & 2.87 \\
6 & 2.01 & 12.61 & 8 & 2.52 \\
7 & 1.92 & 11.54 & 6 & 2.67 \\
8 & 1.95 & 14.66 & 14 & 2.66 \\
9 & 2.05 & 17.2 & 10 & 2.47 \\
10 & 1.83 & 16.2 & 15 & 2.64 \\
11 & 1.88 & 13.47 & 7 & 2.74 \\
12 & 2.04 & 12.6 & 15 & 2.41 \\
13 & 2.01 & 12.4 & 9 & 2.67 \\
14 & 1.87 & 15.6 & 10 & 2.73 \\
15 & 1.81 & 14.8 & 18 & 2.41 \\
16 & 1.87 & 15.8 & 14 & 2.7 \\
17 & 2.11 & 12 & $\mathrm{NP}$ & 2.71 \\
18 & 1.88 & 11.2 & $\mathrm{NP}$ & 2.41 \\
19 & 2.05 & 11.2 & $\mathrm{NP}$ & 2.51 \\
20 & 2.06 & 12.4 & $\mathrm{NP}$ & 2.34 \\
21 & 1.99 & 12.5 & $\mathrm{NP}$ & 2.67 \\
22 & 2.01 & 10 & $\mathrm{NP}$ & 2.31 \\
23 & 1.8 & 12.0 & $\mathrm{NP}$ & 2.55 \\
24 & 1.94 & 10.23 & $\mathrm{NP}$ & 2.42 \\
\hline & & & &
\end{tabular}

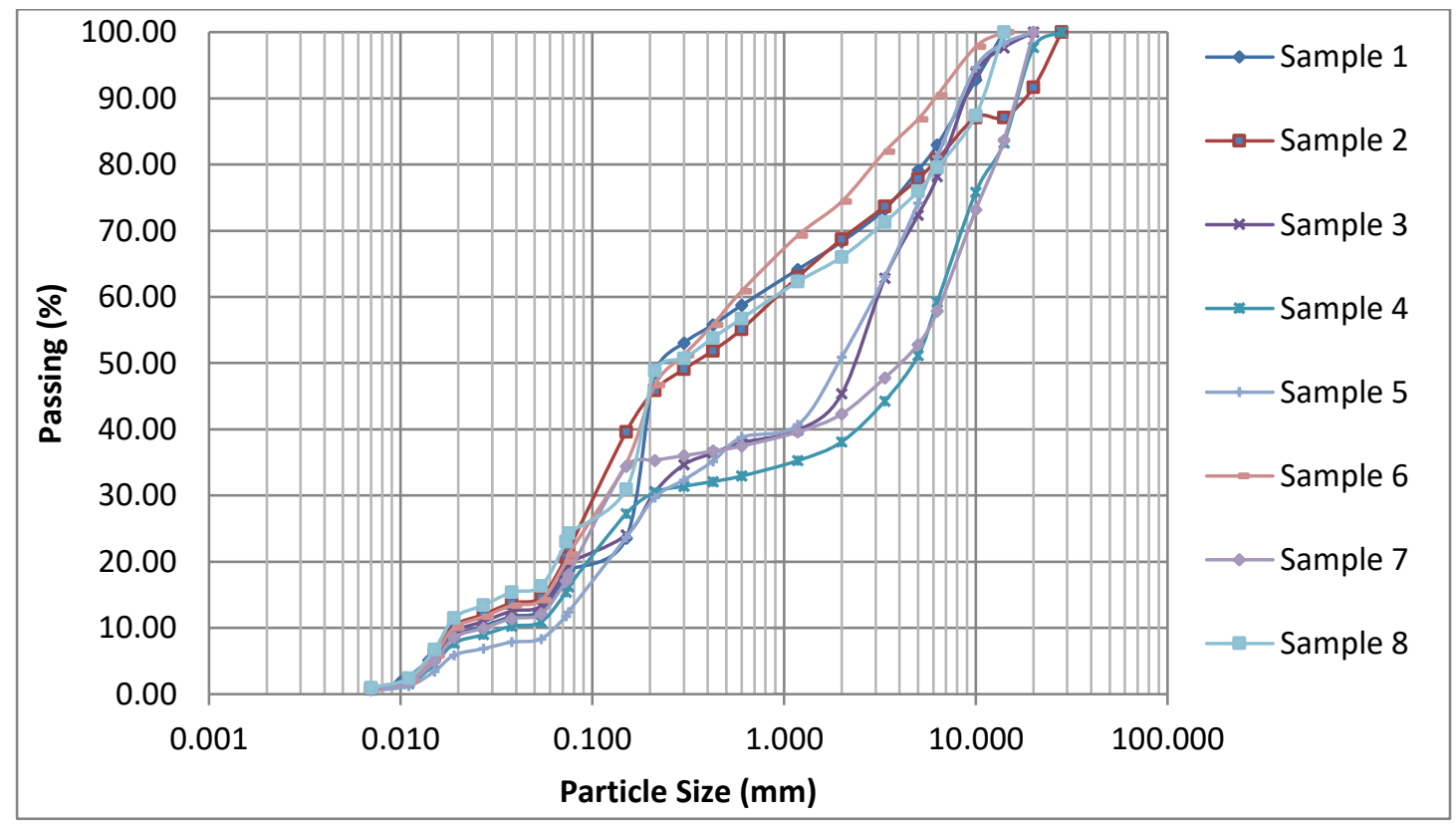

Figure 2: Particle size distribution curve for samples 1 to 8 


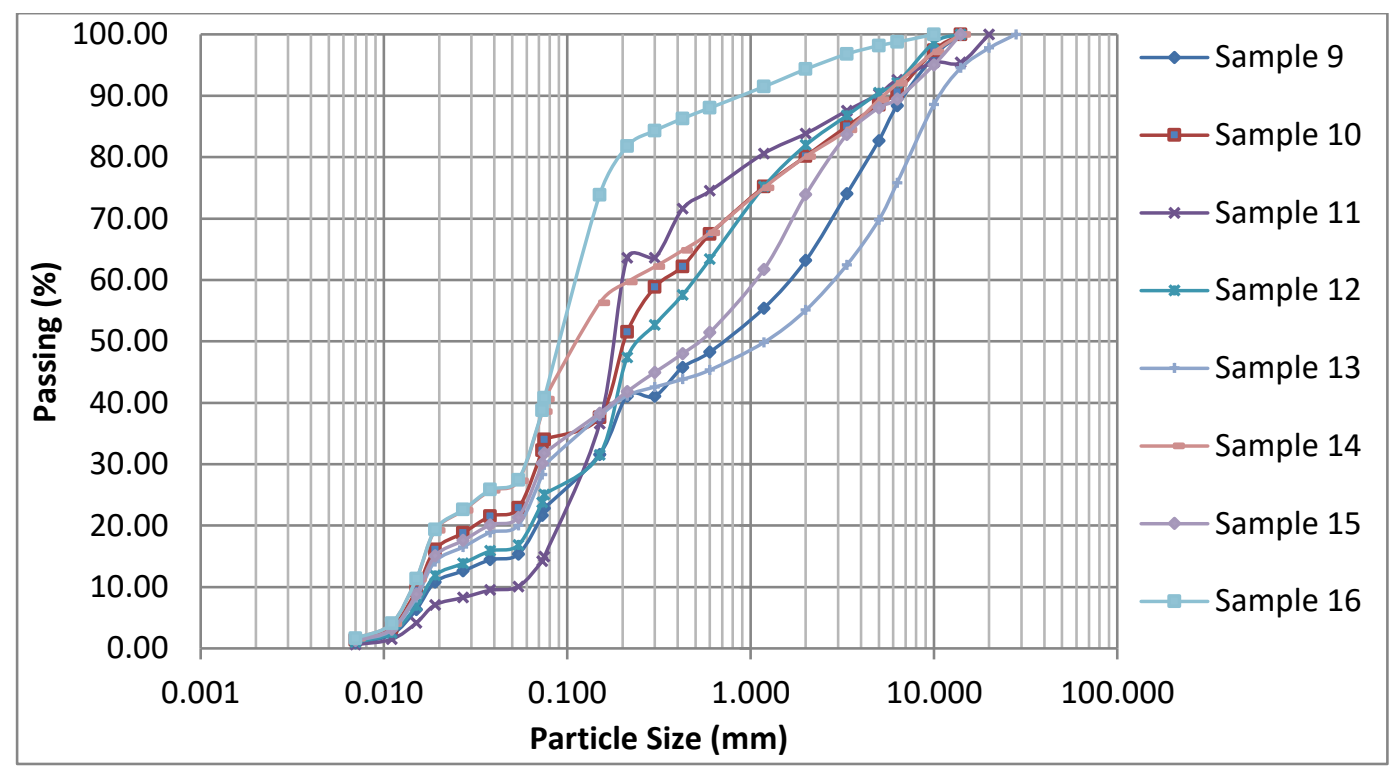

Figure 3: Particle size distribution curve for samples 9 to 16

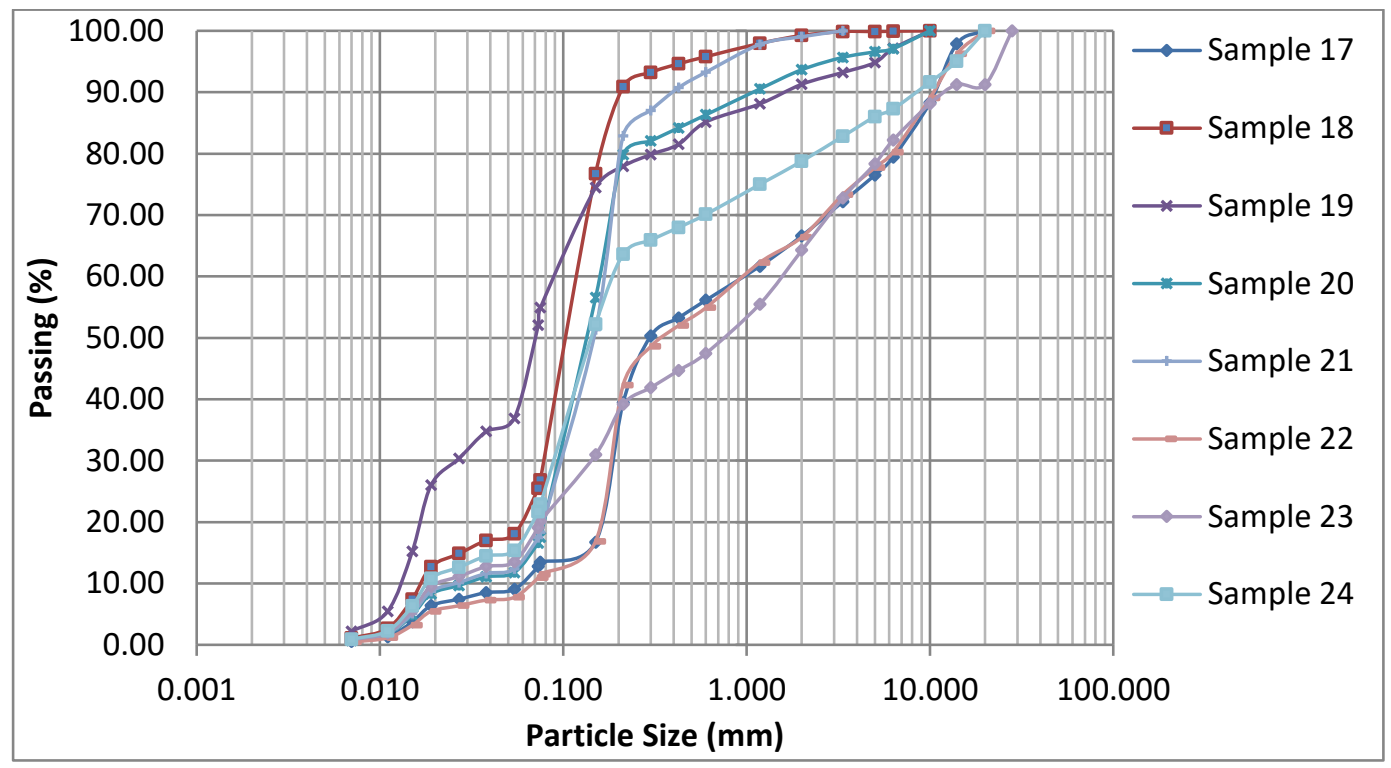

Figure 4: Particle size distribution curve for samples 17 to 24

Figures $5-7$ are plots showing the relationship between mean particle size and hydraulic conductivity. The coefficients of determination $\left(R^{2}\right)$ are 0.9949 , 0.9968 and 0.8918 for sample 1 to 16,17 to 24 and 1 to 24 respectively. This shows that there is a good correlation between particle mean size and hydraulic conductivity among the samples analyzed in this study. However, a stronger correlation were noticed when the plastic and non-plastic samples were separately analyzed. The findings of this study corroborated [3] that mean grain size, the Kruger effective diameter, and effective diameters ranging from $D_{10}$ to $D_{20}$ have high correlation coefficients with measured permeability. In addition, generalized models for the flow were generated as given in Equations 4-6. These Equations represent the models for plastic, non-plastic and the combined samples respectively.

$$
\begin{array}{r}
K=-0.0429 d^{3}+0.7233 d^{2}-1.7613 d+0.5832 \\
K=0.2365 d^{2}+0.1722 d+0.1335 \\
K=-0.0736 d^{3}+1.2372 d^{2}-4.2467 d+4.7249
\end{array}
$$

Where;

$\mathrm{K}=$ hydraulic conductivity $(\mathrm{cm} / \mathrm{s})$

$\mathrm{d}=$ mean particle size $(\mathrm{mm})$ 


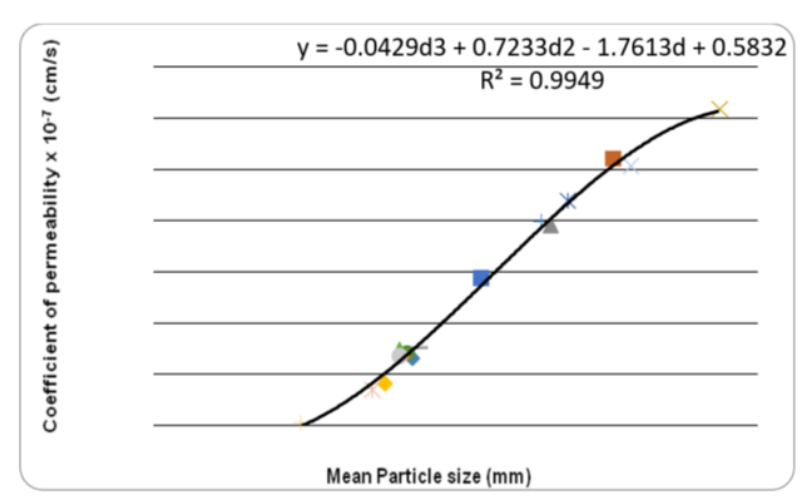

Figure 5: Mean particle size and Hydraulic conductivity curve for samples 1 to 16

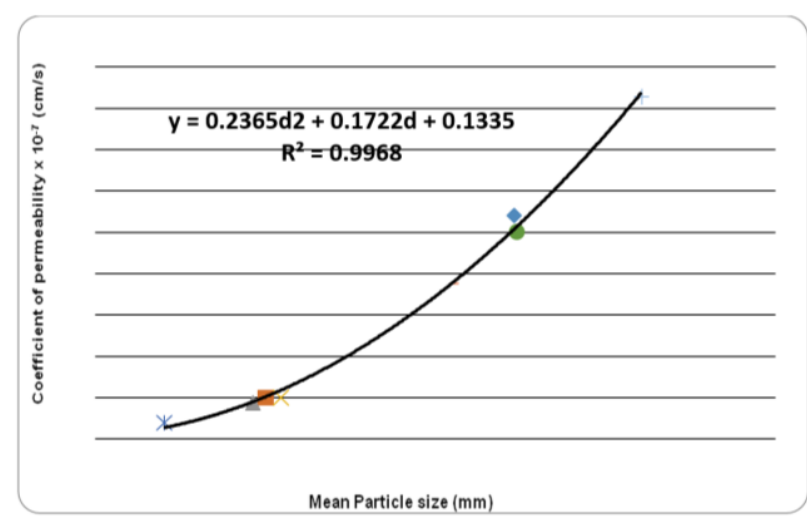

Figure 6: Mean Particle size and Hydraulic conductivity curve for samples 17 to 24

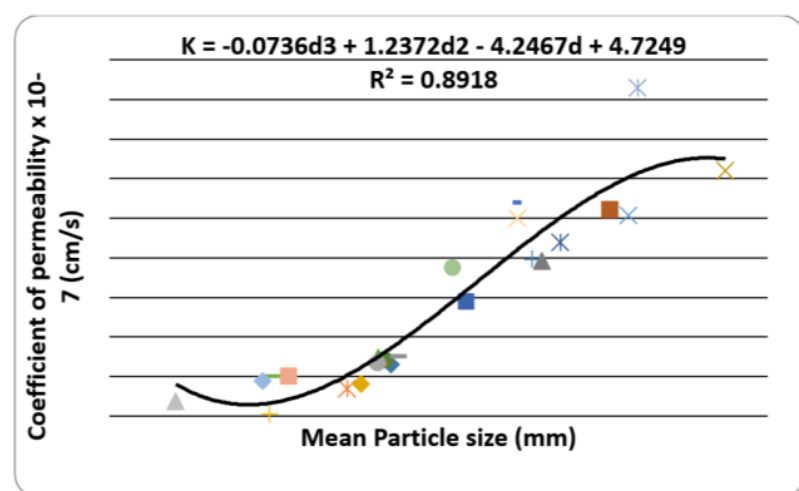

Figure 7: Mean particle size and Hydraulic conductivity curve for samples 1 to 24

\section{CONCLUSIONS}

Measured hydraulic conductivity was correlated with a number of particle-size parameters. The generated plots from this study were compared with the measured hydraulic conductivity and mean particle sizes. The study concluded that there was a strong correlation between hydraulic conductivity and mean particle size of the soil samples used. However, this correlation was stronger when the plastic and non- plastic samples were jointly examined. The generated models can be used to predict the hydraulic conductivity of different soil samples.

\section{REFERENCES}

[1] Dulcey-Leal, E., Molina-Gómez, F. and Bulla-Cruz, L. A. Hydraulic Conductivity in Layered Saturated Soils assessed through a Novel Physical Model. DYNA, 85(205), pp. 119-124. 2018.

[2] Ali, F. C. and Nurullah, A. H. K. Effects of the Particle Shape and Size of Sands on the Hydraulic Conductivity. Acta Geotechnica Slovenica, Volume 2, pp 83-93. 2016.

[3] Daniel, M. D. Permeability, Porosity, and Grain-Size Distribution of selected Pliocene and Quaternary Sediments in the Albuquerque Basin. New Mexico Geology, pp 79-87. 1995.

[4] Ishaku, J.M., Gadzama, E.W., Kaigama, U. Evaluation of empirical formulae for the determination of hydraulic conductivity based on grain-size analysis. Journal of Geology and Mining Research, 4, 105-113. 2011.

[5] Gupta, P., Alam, J. and Muzzammil, M. Influence of thickness and position of the individual layer on the permeability of the stratified soil. Perspectives in Science, 8, pp. 757-759. 2016.

[6] Marshall, T. A relation between permeability and size distribution of pores. European Journal of Soil Science, 9(1), 1-8. 1958.

[7] Freeze, R. A. and Cherry, J. A. Groundwater. Prentice Hall Inc., Englewood Cliffs, New Jersey. 1979.

[8] Mokwa, R. L. and Trimble, N. R. Permeability of Coarse-Grain Soil from Void Space and Pore Distribution in GeoCongress. Reston, VA: American Society of Civil Engineers, pp. 428-435. 2008.

[9] Stewart, M. L., Ward, A. L. and Rector, D. R. A study of pore geometry effects on anisotropy in hydraulic permeability using the lattice-Boltzmann method. Advances in water resources, 29(9), 1328-1340. 2006.

[10] Gamage, K., Screaton, E., Bekins, B. and Aiello, I. Permeability-porosity relationships of subduction zone sediments. Marine Geology, 279(1-4):19-36. 2011.

[11] Daigle, H. and Screaton, E.J. Evolution of Sediment Permeability during Burial and Subduction, Geofluids, 15(1-2):84-105. 2015. 